Full-text Available Online at www.ajol.info and www.bioline.org.br/ja

\title{
The impact of Cow Dung Augmentation for Remediation of Crude Oil Polluted Soil by Eleusine indica
}

\section{${ }^{* 1}$ ESSIEN, EB; IFEANACHO MO; NWACHUKWU GA}

\author{
Department of Biochemistry, Faculty of Chemical Science, University of Port Harcourt, Rivers State, Nigeria \\ 3*: Author for correspondence, Email: amadig99@yahoo.com \\ Phone number: +2348033312154
}

Key words: Crude oil, Cow dung, Contamination, Heavy metals, Eleusine indica

\begin{abstract}
This study was conducted to evaluate the Enhancement of Remediation by Eleusine indica through augmentation of soil with cow dung. The soil was contaminated artificially with $50 \mathrm{~kg}, 75 \mathrm{~kg}$ and $100 \mathrm{~kg}$ crude oil. over 8 weeks period. The study included an assessment of the polycyclic aromatic hydrocarbons (PAHs) and heavy metal (Cd and $\mathrm{Pb}$ ) accumulation in soil of Eleusine indica.More PAHs was lost from soils augmented with cow dung than from the non-augmented soil. The heavy metals (lead) were in the augmented soils than from the non augmented soil, while heavy metal (cadmium) shows an insignificant amount. Significant differences were noticed between the augmented soils and the non-augmented soil $(\mathrm{p}<0.05)$. The results obtained in this study show that augmenting crude oil polluted soils with cow dung will enhance remediation and restoration of crude oil polluted soil. ( ) JASEM
\end{abstract}

\section{http://dx.doi.org/10.4314/jasem.v19i1.14}

\section{Introduction}

In Nigeria, the scourge of environmental pollution has reached a frightening scale in recent years especially in the Niger-Delta region, the largest delta in Africa and the third largest in the world where most of the crude oil in the country is found (HRW, 1999). Since commercial exploration of petroleum started in Nigeria in 1958 (Okoh, 2003), petroleum has continuously grown to be mainstay of the Nigerian economy. However, the exploration of petroleum has led to the pollution of land and water ways. The agricultural lands have become less productive (Dabbs, 1996) and the creeks and the fishing waters have become more or less dead (Okpokwasili and Odokuma; 1990; Odokuma and Ibo, 2002). Several civil unrests due to environmental degradation from oil exploration have also been witnessed in the Niger Delta region of Nigeria (Inoni et al., 2006). Petroleum hydrocarbons are some of the most universally detected organic pollutants in the environment because of the high industrial use of petroleum products worldwide. Phytoremediation is one of the remediation technologies that have been developed to address this problem. Phytoremediation is the use of plants and/or associated microorganisms to remove contain or render harmful material harmless (Cunningham et al., 1996; Schwab and Banks, 1999; Merkl, 2005). It has been shown to be effective for different kinds of pollutants (contaminants) like heavy metals, radio nuclides and broad range of organic pollutants (Schnoor, 2002; Schroder et al., 2002). Heavy metals can be poisonous for macro- and microorganisms through direct influence on the biochemical and physiological procedures, reducing growth, deteriorating cell organelles, and preventing photosynthesis. Regarding the transportation of metals from roots to the aerial parts of the plants, some metals (especially $\mathrm{Pb}$ ) tend to be accumulated in roots more than in aerial parts, because of some barriers that prevent their movement. However, other metals, such as $\mathrm{Cd}$, moves easily in plants (Garbisu and Alkorta, 2001). The efficacy of plants to remediate petroleum polluted soils depends amongst other factors on the nutrient availability in such soil. The ability of cow dung augmentation to enhance the growth of Eleusine indica grown in crude oil polluted soil had been reported in our earlier studies (Njoku et al., 2008). Amadi and Uebari (1992) and Ogboghodo et al (2004) reported that amending crude oil polluted soil with poultry dung improved soil fertility and the growth of maize in such soil. According to Pilon-Smits (2005), the ability of plants to grow quickly is one of the factors that favour phytoremediation. The present study sought to investigate the influence of augmenting soils with cow dung on the potentials of Eleusine indica to clean up crude oil polluted soil. The objectives were to determine if the addition of cow dung to crude oil polluted soil would enhance the ability of Eleusine indica to clean up such soil and to evaluate the impact of cow dung augmentation on the

*Correspondence, Email: amadig99@yahoo.com 
pAHs, heavy metals ( $\mathrm{Pb}$ and $\mathrm{Cd}$ ) contents of crude oil polluted soil.Therefore, the objective of this study is to investigate the ability of Eleusine indica to accumulate olycyclic aromatic hydrocarbon and heavy metals.

\section{MATERIALS AND METHOD}

Source of material: The crude oil was obtained from Nigerian Agip Oil Company (NAOC), Omoku, Rivers State. Young seedlings of Eleusine indica were obtained from their growth medium in the green house at the University of Port Harcourt. Sandy loam soil was collected from the botanical garden at the University of Port Harcourt, and Cow dung used for this experiment was obtained from the abattoir at Rumuodomaya town in slaughter market.

Experimental design: The study was conducted in a green house in the botanical garden of the University of Port Harcourt, Nigeria. Using 21 experimental pots of $30 \mathrm{~cm}$ diameter and $20 \mathrm{~cm}$ depth. Each pot was filled with $5 \mathrm{~kg}$ of sandy loam soil and the pots were then divided into three experimental groups. The experimental groups were treated with crude oil equivalent to $50 \mathrm{~kg}, 75 \mathrm{~kg}$ and $100 \mathrm{~kg}$ respectively. Seven days after treating the soils with crude oil, each experimental group was further divided into two subexperimental groups- one sub-experimental group for each treatment group was augmented with $1 \mathrm{~kg}$ of partially decomposed cow dung using the method described by Ayotamuno et al (2006). The polluted soils were properly mixed with the cow dung using hand trowel. Young seedlings of Eleusine indica were uprooted and sown at a depth of $2 \mathrm{~cm}$ in each pot. The pots were watered at 3 days intervals with $500 \mathrm{mls}$ of water.

Plant harvest: Plants were gently removed from the buckets 2 months after planting. Polycyclic Aromatic Hydrocarbon Analysis: About $2 \mathrm{~g}$ of samples were weighed into a clean extraction container. Extraction solvent (dichloromethane 10ml) was added into the samples and mixed thoroughly and allowed to settle. The mixtures were carefully filtered into clean solvent rinsed extraction bottles using filter paper fitted into Buchner funnels. The extracts were concentrated to $2 \mathrm{ml}$ and then transferred for clean up/separation. $1 \mathrm{~cm}$ of moderately packed glass wool was placed at the bottom of $10 \mathrm{~mm} \mathrm{X} 250 \mathrm{~mm}$ loup chromatographic column. Slurry of $2 \mathrm{~g}$ activated silica in $10 \mathrm{ml}$ methylene chloride was prepared and placed into the chromatographic column. To the top of the column was added $0.5 \mathrm{~cm}$ of sodium sulphate. The column was rinsed with additional $10 \mathrm{ml}$ of methylene chloride.
The column was pre-eluted with $20 \mathrm{ml}$ of dichloromethane. This was allowed to flow through the column at a rate of about 2 minutes until the liquid in the column was just above the sulphate layer. Immediately $1 \mathrm{ml}$ of the extracted sample was transferred into the column. The extraction bottle was rinsed with $1 \mathrm{ml}$ of pentane and added to the column as well

Heavy Metal Analysis: The leaves were washed thoroughly in deionized water to remove soil particles. They were then oven-dried at $70^{\circ} \mathrm{C}$ for 48 hours and their dry weights recorded. Subsamples of dried plant tissue were digested in a mixture of nitric acid and perchloric acid (Merck). The lead and chromium concentrations in the sample were determined by AAS (Atomic Absorption Spectrophotometry, Varian Spectra AA220).

\section{RESULTS AND DISCUSSION}

The results are illustrated in fig 1 below using a bar chart. The concentration of PAH was found to be most in the group with the highest concentration of contaminant. The concentration of PAH in group A (with cow dung) was observed to be more than in group B (without cow dung). The results obtained from soil samples with cow dung were compared with those from soils without cow dung.

The results illustrated in fig 2 below using a bar chart shows that the concentration of $\mathrm{Pb}$ in group $\mathrm{A}$ (with cow dung) was found to be higher than that of group $\mathrm{B}$ (without cow dung). Within the group, it was also observed that the concentration of lead increased as the levels of concentration increased. These values were far higher than that observed for the control groups (group E and F).

Mean $\mathrm{Cd}$ concentration of the various soil samples before and after phytoremediation. The results showed that there was an insignificant amount of $\mathrm{Cd}$ in the various soil samples that were analysed.

The effects of the growth of Eleusine indica on crude oil contaminated soil showed that without augmentation with cow dung, Eleusine indica can enhance the removal of PAH from soil contaminated with crude oil. However, according to Adedokun and Ataga (2007), soil amendments or additives are needed to increase the activities of microbes and for effective bioremediation of polluted soil. The result from the current study shows that efficacy of Eleusine indica to remove $\mathrm{PAH}$ from soil can be enhanced with the amendment of such soil with cow dung. This is similar to what some earlier researchers have noticed. For instance, Mbah et al (2009) reported that amendment 
of spent oil contaminated soil with organic wastes led to improved soil physicalmproperties and increased agronomic parameters of such soil. While Okolo et al. (2005) reported increased degradation of crude oil in soil augmented with poultry manure.The implication of the influence of cow dung on the removal of crude oil by is that the addition of cow dung Eleusine indica can be appropriately used to remove crude oil from soils or at least reduce the level of crude oil in soils to a manageable level. More so, the use of cow dung as the source of manure in this study is significant because it reduces the cost of using inorganic fertilizers which further reduces the cost of phytoremediation. In addition since cow dung can be found in almost all parts of the country, it can easily be obtained at little or no cost. This also reduces the cost of cleaning up crude oil polluted soils. However, excess cow dung should not be used in this type of study as it may make the microbes to abandon the crude oil and feed on the nutrients provided by the cow dung or any other form of manure.

That contamination with crude oil increased the Lead concentration of the soil. Heavy metal is defined as any element with metallic characteristics, such as density, conductivity, stability as cations, and an atomic number greater than 20 (Raskin et al., 1994). Heavy metal pollution is a crucial environ-mental concern throughout the world. Lead in contaminated soil samples were significantly high than in uncontaminated soil samples. The mean $\mathrm{Pb}$ concentration increased as the level of pollution increased. This showed that Eleusine indica augmented with cow dung were effective in significant in reducing the concentrations of $\mathrm{Pb}$ in the soil. Ogbo \& Okhuoya (2011) Investigated the Bioavailability Of Some Heavy Metals In Crude Oil Contaminated Soils Remediated With Pleurotus Tuber-Regium Fr. Singer. while Nadia et al, (2012) performed a pot culture experiments using radish (Raphanus sativus L.) to investigate lead $(\mathrm{Pb})$ phytotoxic effects on antioxidant enzymes and other early warning biomarkers of soil $\mathrm{Pb}$ exposure. Essiett et al, (2010) conducted a field study to assess heavy metal concentrations in plants grown on crude oil contaminated soil in Akwa Ibom State. These help to facilitate the activities of crude oil degrading microbes required in the remediation of crude oil polluted soil. It also suggests that cow dung helps the soil to increase its water retention capacity which facilitates plant growth.

Conclusion and recommendation: From the findings of this study, it has been observed that cow dung augmentation of crude oil polluted soil can help to enhance the efficiency of Eleusine indica in reducing the quantity of PAH and heavy metals $(\mathrm{Pb})$ in the soil. However, it is being recommended here that cow dung addition should be at a moderate level to avoid the symbiotic microbes at the rhizosphere from abandoning feeding on crude oil for the nutrients in the cow dung.

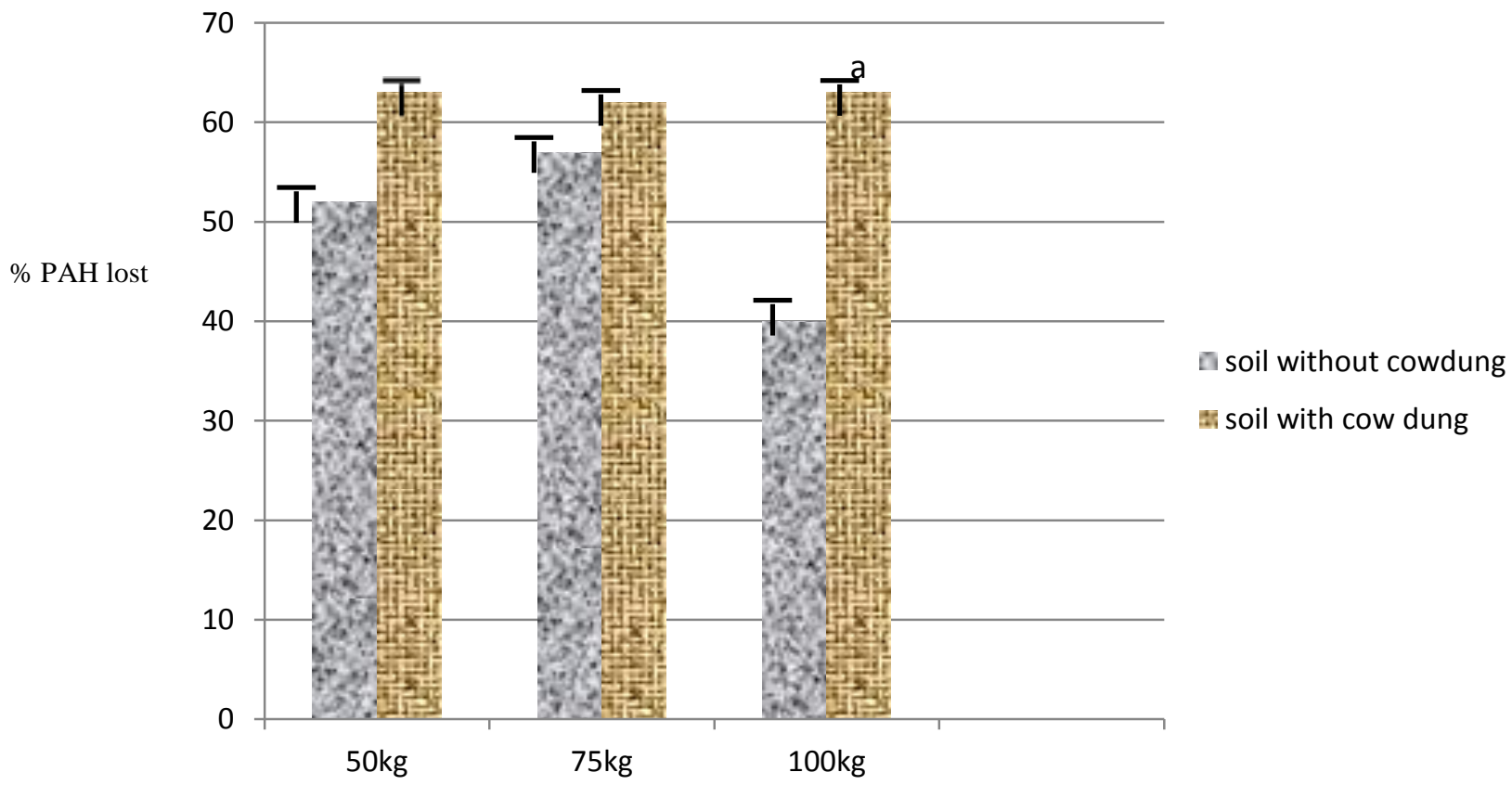

Amount of crude oil added to the soil 
Fig 1: The amount of poly aromatic hydrocarbon lost (PAH) from the cowdung added to crude oil conterminated soil and conterminated soil without cowdung. a means significantly different between the soil with cowdung and soil without cowdung at $\mathrm{P}<0.05$.

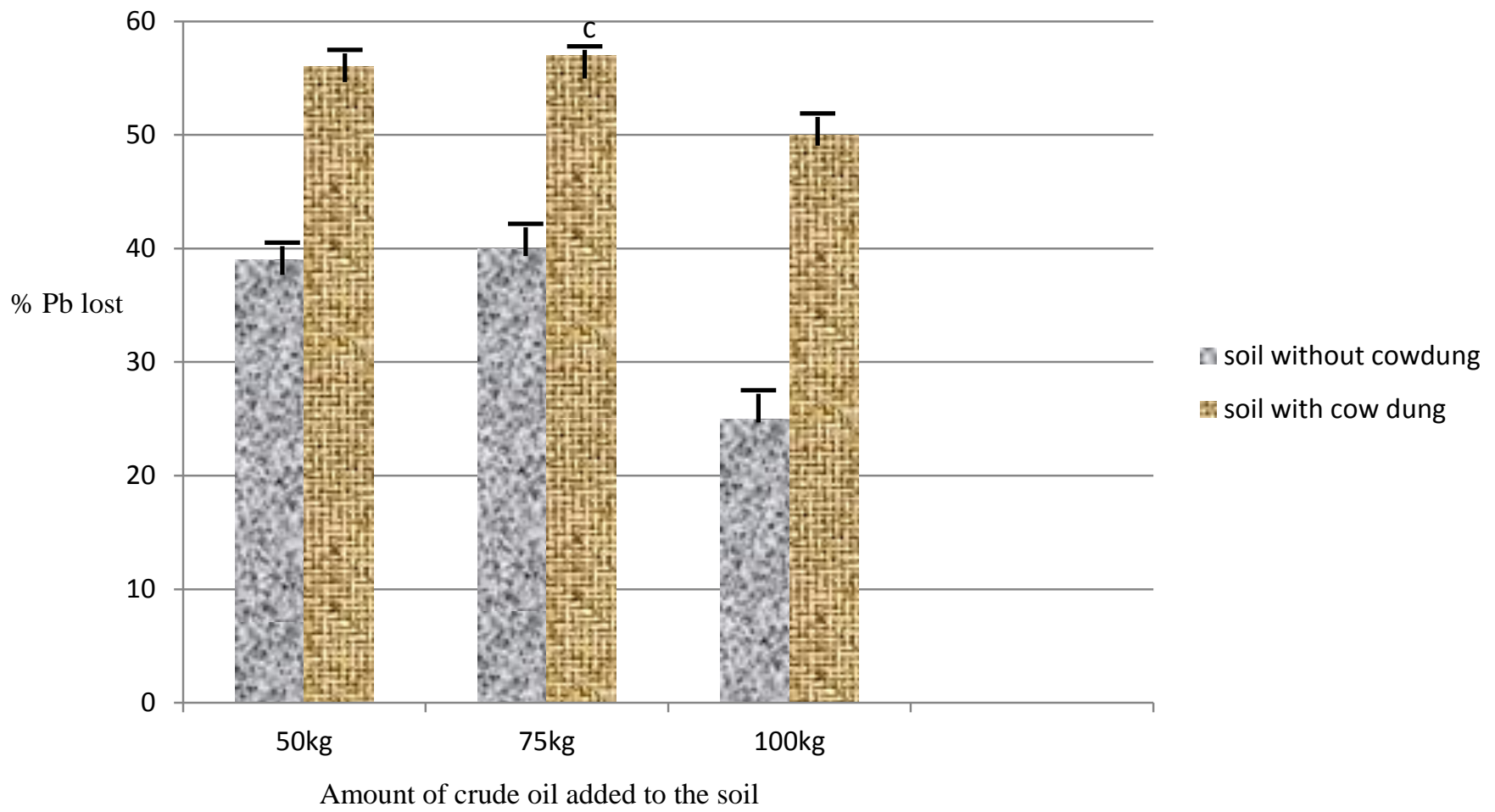

Fig 2. The amount of lead $(\mathrm{Pb})$ lost from the cowdung added to crude oil conterminated soil and conterminated soil without cowdung. $\mathrm{c}$ means significantly different between the soil with cowdung and soil without cowdung at $\mathrm{P}<0.05$.

\section{REFERENCES}

Adedokun O.M. and A.E. Ataga, (2007). Effects of Amendments and Bioaugumentation of Soil Polluted with Crude Oil, Automotive Gasoline Oil, and Spent Engine Oil on the Growth of Cowpea (Vigna unguiculata L. Walp). Scient. Res. Essay.,

2(5):147-149.

Amadi, A. and Y. UeBari,( 1992). Use of Poultry Manure for Amendment of oil Polluted Soils in relation to Growth of Maize (Zea mays L). Environ. Intern. 18: 521-527.

Ayotamuno, J.M., R.B. Kogbara and M.O. Taleat,( 2006). Bioremediation of a petroleumHydrocarbon Polluted Agricultural Soil at different levels of Water Application in Port Harcourt,

Nigeria. J Food, Agric. Environ. 4(3\&4): 214-217.

Cunningham, S.D., Anderson, T.A., Schwab, A.P. and Hsu, F.C. (1996). Phytoremediation of Oil
Contaminated with Organic Pollutants. Advances in Agronomy 56: 55-114

Dabbs, W.C. (1996). Oil Production and Environmental Damage.

http://www.american.edu.TED/hpl.htm.

Essiett, U.A., Effiong, G.S., Ogbemudia, F.O. and Bruno, E.J. (2010). Heavy Metal Concentrations in Plants Growing in Crude Oil Contaminated Soil in Akwa Ibom

State, South- Eastern Nigeria. African Journal of Pharmacy and Pharmacology 4(7): 465470.HRW. (1999). The Price of Oil. Available at: http://www.hrw.org/reports/ 1999/nigeria/index.htm Human Right Watch.

Inoni, O.E., Omotor, D.G. and Adun, F.N. (2006) The Effect of Oil Spillage on Crop Yield and Farm Income in Delta State, Nigeria. Journal of Central European Agriculture 7(1): 41-49 
Mbah, C.N., J.N. Nwite, I.A. Nweke, 2009. Amelioration of Spent Oil Contaminated Ultisol with Organic Wastes and its Effect on Soil Properties and Maize (Zea mays L)

Yield. World J. Agric. Sci., 5(2): 163-168.282 J. Appl. Sci. Res., 8(1): 277-282.

Merkl, N., R. Schutze-Kraft, C. Infante,( 2005). Phytoremediation in the tropics - influence of heavy crude oil on root morphology characteristics of graminoids. Environ. Poll., 138(1): 86-91

Nadia, A.H., Houria, A., Souad, D., Miloud, S. and Abdelkader Aoues (2012). Phytoremediation Potential of Raphanus Sativus L. for Lead Contaminated Soil. Acta Biologica Szegediensis 56(1): 43-49

Njoku, K.L., 2008. Evaluation of Glycine max and Lycopersicon esculentum in the remediation of crude oil polluted soil. A thesis submitted to the school of postgraduate studies,

University of Lagos, Akoka Lagos, Nigeria, pp: 187.

Njoku, K.L., M.O. Akinola, B.O. Oboh, 2008. Growth and Performance of Glycine max L. (Merrill) Grown in Crude Oil Contaminated Soil Augmented With Cow Dung. Nat. Sci., 6(1): 46-56

Njoku, K.L., M.O. Akinola, B.O. Oboh, 2009. Phytoremediation of crude oil contaminated soil: the effect of growth of Glycine max on the physico-chemistry and crude oil contents of soil. Nat. Sci., 7(10): 79-87
Ogboghodo, I., E. Erebor, I. Osemwota, H. Isitekale, 2004. The effects of application of poultry manure to crude oil polluted soils on maize growth and soil properties. Environ. Monit. Assess. 96: 153-161.

Okolo, J.C., E.N. Amadi, C.T.I. Odu, 2005. Effects of Soil Treatments Containing Poultry Manure on Crude Oil Degradation in a Sandy Loam Soil. Appl. Ecol. Environ. Res., 3(1): 47-53.

Okpokwasili, G.C. and Odokuma L.O. (1990). Effect of Salinity on Biodegradation of Oil Spills Dispersants. Waste Management 10: 141-146

Pilon-Smits, E., 2005. Phytoremediation. Annual Review of Plant Biology, 56: 15-19.

Raskin, I., Kumar, P.B.A., Dushenkov, S. and Salt, D.E. (1994). Bioconcentration of heavy metals by plants. Current Opinions in Biotechnology 5(3): 285-290.

Schnoor, J.L. (2002). Phytoremediation of Soil and Groundwater: Technology Evaluation Report TE-02-01. Groundwater Remediation Technologies Analysis Centre (GWRTAC). www.gwrtac.org.

Schwab, A.P. and Bank, M.K. (1999).

Phytoremediation of Petroleum Contaminated Soils. In: Bioremediation of Contaminated Soils, pp 783-795. (Andriano, D.C., Bollag, J.M., Frankenberger, W.T. Jr, and Sims, R.C. Eds). American Society of Agronomy, Crop Science Society of America, Soil Science Society of America, Madison 